\title{
“EVALUATION” OR “ASSESSMENT”AS A RESULT OF DETERMINATION OF A QUALITY LEVEL OF STUDENTS’ KNOWLEDGE
}

\section{Zvarych I.M., Doctor of Sciences (Kyiv)}

Education in Ukraine is the basis of intellectual, cultural, spiritual, social and economic development of society; it should be obtained as a result of consistent, systematic, purposeful assimilation of knowledge, ensuring comprehensive development of the student's personality. Higher education in Ukraine is developed and reformed mainly due to the state development and is perceived as an integral structural element of the state system. The author emphasizes that education in Ukraine has always combined the education and upbringing of young people, their scientific activities, in particular, scientific research in various fields of science.

The development of education in the present conditions poses many new tasks related to improving the quality of students' training with higher education. An important place in the preparation process is the assessment of students' knowledge quality level in the study of the subject.

We consider the pedagogical assessment of students' knowledge quality as two important links in learning - as a process and as a result: on the one hand, the ability of the teacher to convey meaningful knowledge to students in learning subject, and on the other - to determine the quality of their knowledge gained through the accumulation of information, contained in textbooks, on the Internet, obtained from the teacher. Our study clarifies the use of the term pedagogical assessment of the quality of knowledge, which is interpreted in American literature as "evaluation" and "assessment". These two terms are very close in meaning and are often used in the evaluation process as synonyms, replacing each other, and this is what makes it difficult to translate and use them in the initial process. The significance of the meaning of these two terms is highlighted in the article and the expediency of their use in the process of assessing the quality level of students' knowledge is substantiated; in particular, the author pays special attention tothe function of assessment for the development of students and the formation of their personality.

Key words: assessment, data gathering, diagnosis, evaluation, learning subject, monitoring, students' knowledge level, systematic process.

Зварич І.М. Оцінка чи оцінювання як результат визначення рівня якості знань студентів. Освіта в Україні є основою інтелектуального, культурного, духовного, соціального та економічного розвитку суспільства, іiі потрібно здобути в результаті послідовного, систематичного, цілеспрямованого засвоєння знань, забезпечення всебічного розвитку особистості студента. Вища освіта в Україні розвивається і реформується в основному за рахунок державного розвитку та сприймається як невід'ємний структурний елемент державної системи. У статті підкреслюється, що освіта в Україні завжди поєднувала і поєднує в собі навчання і виховання молоді, iї наукову діяльність, зокрема, наукові дослідження в різних галузях науки.

(C) Zvarych I.M., 2019 
Розвиток освіти в сучасних умовах ставить чимало нових завдань, пов'язаних iз підвищенням якості підготовки фахівців із вищою освітою. Важливе місце в процесі підготовки посідає оцінювання рівня якості знань студентів у вивченні навчального предмета.

Педагогічне оцінювання рівня якості знань студентів ми розглядаємо як дві важливі ланки у навчанні - як процес і як його результат: $з$ одного боку, здатність викладача передати студентам змістовні знання 3 навчальної дисципліни, а 3 іншого - визначити рівень якості їхніх знань, здобутих шляхом накопичення інформації, зосередженої в підручниках, в Інтернеті, отриманих від викладача. У нашому дослідженні з'ясовується використання терміну «педагогічне оцінювання» рівня якості знань, яке в американській літературі трактується як «evaluation» та «assessment». Ці два терміни дуже близькі за значенням і часто вживаються як синоніми, замінюючи один одного, і саме цим становлять трудність у перекладі та використанні їх у начальному процесі. У статті висвітлюється смисл цих двох термінів і обгрунтовується доречність уживання їх у процесі оцінювання рівня знань студентів, зокрема виокремлюється функція оцінювання для розвитку студентів і формування їхньої особистості.

Ключові слова: діагностування, збирання даних, моніторинг, навчальний предмет, оцінка, оцінювання, рівень знань студентів, систематичний процес.

Зварич И.Н. Оценка или оценивание как результат определения уровня качества знаний студентов. Образование в Украине является основой интеллектуального, культурного, духовного, социального и экономического развития общества, его нужно получить в результате последовательного, систематического, целенаправленного усвоения знаний, всестороннего развития личности студента. Высшее образование в Украине развивается и реформируется в основном за счет государственного развития и воспринимается как неотъемлемый структурный элемент государственной системы. $\mathrm{B}$ статье подчеркивается, что образование в Украине всегда сочетало и сочетает в себе обученияе и воспитание молодежи, ее научную деятельность, в частности, научные исследования в различных областях науки.

Развитие образования в современных условиях ставит много новых задач, связанных с повышением качества подготовки специалистов с высшим образованием. Важное место в процессе подготовки занимает оценивание уровня знаний студентов при изучении учебного предмета.

Педагогическое оценивание уровня знаний студентов мы рассматриваем как важные звенья в обучении - как процесс и как его результат: с одной стороны, способность преподавателя передать студентам содержательные знания по дисциплине, а с другой - определить уровень качества их знаний, полученных путем накопления информации, сосредоточенной в учебниках, в Интернете, полученных от преподавателя. В нашем исследовании выясняется использование термина «педагогическое оценивание» уровня знаний, который в американской литературе трактуется как «evaluation» и «assessment». Эти два термина очень близки по значению и часто используются в процессе оценки как синонимы, заменяя друг друга, и именно этим представляют трудность в переводе и использовании их в учебном процессе. В статье освещается смысл этих двух терминов и обосновывается уместность употребления их в процессе оценки 
качественного уровня знаний студентов, в частности выделяется функция оценивания для развития студентов и формирования их личности.

Ключевые слова: диагностирования, мониторинг, оценивание, оценка, сбор данных, систематический процесс, уровень знаний студентов, учебный предмет.

Abstract. Education is a determining factor in the scientific, cultural, economic, political, socio-economic potential of any nation, the basis for the country's strategic development, the rational use of national resources, the affirmation of the country's competitiveness in the international community, and the well-being of people. Education always reflects the interests of society and fulfills its social order, generates a public demand for knowledge and development prospects, changes under the influence of time, social, economic and other factors.

The main task is to provide the conditions for the development of creative self-realization for every citizen, to educate a generation capable of learning through life and to uphold the values of civil society, which necessitates the reform of higher education and the need for a radical modernization of higher learning institutions. It is important to build a modern higher education in the context of civilizational development and international requirements for education of the 21 st century. The problem of the quality of Ukrainian education in the conditions of an independent state establishment now arises as never before. One of the conditions for improving the quality of higher education is the training of pedagogical the staff of higher education, their professional improvement - ensuring a high level of professional knowledge and pedagogical competence of teachers who carry out the educational process, that is very important for further Education system development.

The degree of scientific research of the issue. Scientists are attracted by the importance of using the terms of "evaluation" and "assessment" in the process of determining students' knowledge level of quality. These two terms are very close in meaning and are often used in the evaluation process as synonyms, replacing each other, and this is what makes them difficult to translate and use in the initial process.

J. Wilmut has studied the process of determining students' knowledge level, gathering diagnostic data for measuring students' results in the process of learning subject. W. Harlen highlights student knowledge in the practice activity. 
The aim of the study: to estimate the use of terms "evaluation" and "assessment" in the process of determining students' knowledge level quality; to clarify and highlight the meaning of these two terms and analyze their appropriateness of usage in the pedagogical process as a result of measuring the students' knowledge quality level, in particular, to distinguish the function of assessment of students' development and formation of their personality.

The topicality of the research. The evaluation of students' knowledge level is an important task and not very easy, because it is said, on the one hand, about a certain report of students to the teacher, and on the other one, the students must understand how fair the teacher's requirements are. The process of students' knowledge evaluation to a large extent influences the formation of openness, trust in students, and their respect for the teacher, who certainly has a significant impact on the students' success of learning a subject and, moreover, on their formation as persons. The students' knowledge evaluation is the thorough determination of a correspondence between what subject knowledge level they have and what they should study to know. The teacher not only implements the evaluation process but also correlates the identified students' knowledge with the curriculum. A comparison of the actual knowledge of students with the program requirements derives from the very teaching essence as purposeful creativity, education and upbringing. The evaluation of students' knowledge level is transformed into a complex process, which requires the identification of students'actual knowledge in relation to the subject program requirements. It is very important to determine the students' knowledge level correctly in the process of learning the subject.

The main part of scientific research. The assessment of students' knowledge quality In Ukraine and the US as well, gives the opportunity to distinguish the common issues, namely the reform of education, which guarantees quality education and upbringing of young people at all stages of the educational process; ensuring students' international competitiveness; improving the quality of students' knowledge level through a variety of types and forms of educational institutions, programs to prepare students for professional activity, in particular the provision of high quality education and upbringing of young people, through the introduction of better value, and the involvement of highly 
qualified specialists, including scientists, employees of public and political organizations.

The system of assessment in US is one of the administrative tools higher education management that is studied and used to modernize higher education institutions and determine the quality of educational services, which is at the same time a major factor in public education policy. Since the state administration depends on the quality education and qualified training of specialists, it is necessary to improve modern methods of teaching disciplines, professional activity of teachers, their pedagogical competence, skill, awareness and raise the standards of the educational process for improving the process of "assessment" and "evaluation" in countries.

There are a lot of scientists investigatingthe problem of students' knowledge evaluation. Among them are: I. Bulah, W. Harlen, D. Wiliam, J. Wilmut, W. Harris, and others. The researchers more or less agree on the fact that regular and sufficient control and verification will promote the timely detection of gaps in the students' knowledge and skills; refreshment and systematizationof the subject learning material; determination of the level of readiness to gain knowledge and learn a new subject material; the responsible formation of skills or selfexamination of the level of knowledge and focused work to study a subject deeply and fruitfully, and stimulate students' responsibility. Studying these scholars' research, we highlighted the evaluation of students' development and the formation of one's personality.

J. Wilmut, who studies these two definitions of students' knowledge level, states that "evaluation" is the definition of the term "assessment" as a general category, and "assessment" is a pedagogic evaluation. Evaluation ("evaluation") is a systematic process of gathering diagnostic data and their processing, which leads to the value of the results obtained [7: 19].

W. Harlen highlights that the pedagogic assessment of students' knowledge quality level is a series of processes used to determine what students know and how they are using their knowledge in the practice activity. Therefore, the knowledge quality level assessment as a general category has the following functions: control and reporting; evaluation for development; gaining knowledge and comprehension [2: 4]. Assessment monitoring and reporting are carried out to regulate, determine the impact of a program or an initiative, a certification ora 
selection. J. Wilmut notes that evaluations for monitoring and reporting are used for strategic or policy purposes to identify the results of students' knowledge level, decision-making and reporting at the local, regional, and state levels. Evaluation for development involves diagnosis, leading to decision-making and process improvement, and can combine quantitative and qualitative provision methods: formal methods, observational and narrative styles for rendering, reporting on stakeholder experiences [7: 20].

Assessment for acquiring knowledge and comprehension is carried out in order to thoroughly master the program material and learning the subject deeply. Thus, the assessment as a general category of "evaluation" is a systematic process that uses the data of student diagnosis and needs to be processed, includes the decision making, establishes value, uses objective criteria and determines decisionmaking: refinement, choice, certification, and reporting [7: 20]. J. Wilmut emphasizes that the pedagogic assessment process is closely linked to the studying process, and considers pedagogic assessment as forming and final. According to his view, the formative pedagogic assessment of students' knowledge level is a process of finding new fundamentals for evaluation and processing, the results of the knowledge quality level are used to determine which stage students are at and how to diagnose them best.

The formative pedagogic assessment can be a part of effective planning of teaching and studying focused on how students gather material for studying and master it; the basis for determining the orientation characteristics of the education process in the group or class (assessment system). The pedagogic final evaluation includes certification of individual achievements, provision information for choice, establishment of program effectiveness, obtaining information necessary for monitoring and reporting [7:21].

The scholar I. Bulah underlines that the evaluation is a process of forming the conclusions based on a comparison of quantitative indicators derived from different sources with standards and carried out in order to improve education programs. According to her opinion, assessment is the process of finishing and processing (systematization, analysis, generalization, etc.). The researcher highlights that measuring is the process of assigning a numerical value to a particular property 
person, in accordance with his or her quantitative manifestation, using the defined measurement rules clearly [1: 11].

Pedagogic evaluation of students' knowledge level at Higher Education Institutions is directly related to the problem of ensuring education quality. As pedagogic evaluation makes it possible to diagnose the quality of professional training of future specialists, there is a need for a special analysis of the economic, political and public factors of influence on a high-quality functioning of the higher education system, which is characterized by scientifically substantiated and practically verified pedagogic bases for evaluation of students' knowledge level.

A very important thought concernsthe assessment of the ability to learna subject. D. Wiliam notes that the prevailing view of education is the provided instruction of reasonable quality; it need not be adaptive to the needs of learners. It is assumed either that well-designed instruction would be effective for the majority of students for whom it was intended (with others being assigned to remedial activities) or that the causes of any failures to learn lay within the individual learner (the material is just too hard for them, and they should instead pursue other, and generally less academic, avenues) [6]. We absolutely agree with D. Wiliam, that a well-designed task instruction is one of the advantages of evaluating students' knowledge level because they spend just a little time on task comprehension and have more time for doing exercises and demonstrating their knowledge level quality.

It should be noted that instruction comprehension is one of the approaches to success in the period of evaluating students' knowledge level. Well-designed instruction is necessary for students, especially with a low level of knowledge, to understand a task. However, one may look, read but do not understand what the idea of the task is and how it should be done. Thus, students need to have a sufficient knowledge level not only for understanding the implementation instructions but also to fulfill these tasks.

It is very important to note the ideas of the Greek philosopher Platonic Socrates about children with a low level of knowledge, especially concerning students with disabilities. Socrates was not only a teacher and mentor for his disciples but also a teacher of justice and objectivity; a man of high intellect, wit, and intelligence; a lecturer of real examples for education, bringing up and training. Socrates believed 
that learning was a burning flame, not a capacity filling, so he was trying to find a spark from the students, which would excite them to study, to know the truth. The students were his friends, he was close to them in spirit and heart, but with such an attitude to each other, everyone remained as he was. He had no special rules for assessment of his students' knowledge, a certain model for characterization which could match their characteristics and, in particular, their differences. He never judged his students according to their mind, but was equal among equal and a friend among friends [5].

Thus, the Greek scholar sets to the students' knowledge evaluation of the development of students' natural abilities which are constantly developing. It means that the development process is permanent, so it is possible to distinguish one more type of assessment - evaluation of a student's development and formation of personality.

W. Harris underlines that evaluation is the systematic process of judging the worth, desirability, effectiveness or adequacy of something according to definite criteria and purposes. The judgment is based upon a careful comparison of observation data with criteria standards. He notes that precise definitions of what is to be apprised, clearly stated purposes, specific standards for the criteria traits, accurate observations and measurements, and logical conclusions are the half-marks of valid evaluation [3].

First of all, we should convince students that their knowledge and skills are necessary not for checking and giving them grades, their formal reports, and diplomas, but for their future profession, career, and life.

A grade becomes an effective stimulus in teaching if it is fair and objective and based on the same requirements for each student during the assessment. It is particularly important for students to feel and admit the teacher's fair and good approach. The assessment of students' progress must not depend on their behavior or some problems related to the misunderstanding between teacher and student, which often occurs in pedagogical practice [6].

Long pedagogical practice and rich experience show that very often the same students have different grades in the same subjects with different teachers. They have the same knowledge level, but different marks. Some teachers of foreign language were asked what they valued most of all in their students' answers. Some of them mentioned language competence and its richness in images, sharpness and 
emotional character; others pointed out the adoption of the program material and independence in judgment and conclusions; the others the capability of analyzing and originality of answers.

Thus, we should pay attention to the essential changes going on in the current education system; improve the teachers' mastering of the newest achievements in the national and foreign pedagogy, in particular, in modern technologies of assessment.

Conclusion. Thus, the assessment as a general category is the determination of students' knowledge quality level from the learning subject. Pedagogic evaluation reflects the process of interaction between the teacher and the student, where the quality of the acquired knowledge is determined, which significantly influences the further learning process. Pedagogic evaluation combines sensory-emotional and rational factors that enhance its importance in the context of providing successful individual students' development.

For the best results in the process in studying a foreign language and a subject as well the following must be done: increasing the number of students exchanges; expanding educational technology and distance learning opportunities; ensuring that all American students learn at least one foreign language, and foreign cultures; sharing information about good education practices with other countries; studying the research innovations of different countries and borrowing the suitable methods for the USA; sharing information about good education and studying foreign languages.Studying a foreign language and becoming bilingual opens one's mind and creates opportunities to communicate with other people. Knowinga foreign language can be the key to a lasting peace between enemies and of course, the best way to make friends.

Research results and discussion. Using terms of determining the results of students' knowledge level interpreted in American literature as "evaluation" and "assessment"is very important in lecturers' pedagogical activity. These two terms are very close in meaning and are often used in the evaluation process as synonyms, replacing each other, that is why we have discussed them at the meeting of our department of Foreign Philology and Translation.The research results have been discussed at international conferences and some aspects have been observed in magazines.

Perspectives of further research. This study does not exhaust all aspects in comparing terms of "evaluation" and "assessment" and using 
them properly in the process of learning subject, particularly in the evaluation of students' knowledge level. It should be also studied and analyzed using the terms of "judgment" and "determine" to estimatethe students' results in the process of studying the subject because in American literature these terms are also used.

\section{LITERATURE}

1. Bulakh I. Concepts and categories of pedagogic diagnostics. Educational and methodical and reference materials for teaching staff. Part I. Theory / ed. Iryna Bulakh. K.: Master-class, 2005. P. 11-18.

2. Harlen W. Values and Evaluation in Education. Evaluation in Education in Straughan R. \& Wringley J. London: Harper \& Row, 1980. P. 4.

3. Harris W. The nature and functions of educational evaluation. Peabody Journal of Education. XLVI. September 1968. P. 95-99.

4. Zvarych I.M. The USA teachers' pedagogical activity evaluation at the higher learning institutions (the second part of the XX-th century and the beginning of the XXI-st century). K.: Feniks, 2014. 342 p.

5. Zvarych I.M., Marushkevych A.A. The education quality measuring: American experience. EURERA: Social and Humanities. 2018. Volume 1 (13). P. 54-63.

6. Wiliam D. What is the assessment for learning? URL: https://doi.org/10.1016/j.stueduc.2011.03.001Getrightsandcontent (accessed 17.08.2019).

7. Wilmut J. Two values and two definitions of the concept of evaluation. Fundamentals of pedagogical evaluation. Part I. Theory: Educational and methodological and reference materials for teaching staff / ed. Iryna Bulakh. K.: Master-class, 2005. P. 19-21.

\section{REFERENCES}

Bulakh, I. (2005). Concepts and categories of pedagogic diagnostics. Educational and methodical and reference materials for teaching staff. Part I. Theory. Iryna Bulakh (Ed.). Kyiv: Master-class [in Ukrainian].

Harlen, W. (1980). Values and Evaluation in Education. Evaluation in Education in Straughan R. \& Wringley J. London: Harper \& Row [in English].

Harris, W. (1968). The nature and functions of educational evaluation. Peabody Journal of Education. London, XLVI, September [in English].

Wiliam, D. What is the assessment for learning? Available at: https://doi.org/10.1016/j.stueduc.2011.03.001 Get rightsandcontent [Accessed 17 Aug. 2019] [in English]. 
Wilmut, J. (2005). Two values and two definitions of the concept of evaluation. Fundamentals of pedagogical evaluation. Part I. Theory: Educational and methodological and reference materials for teaching staff. K.: Master-class, pp. 19-21 [in Ukrainian].

Zvarych, I.M. (2014). The USA teachers' pedagogical activity evaluation at the higher learning institutions (the second part of the $X X$-th century and the beginning of the XXI-st century). K.: Feniks [in Ukrainian].

Zvarych, I.M. and Marushkevych, A.A. (2018). The education quality measuring: American experience. EURERA: Social and Humanities, 1 (13), pp. 54-63 [in English].

Стаття надійшла до редакиії: 10.09.2019

Зварич Ірина Миколаївна, докт. пед. наук, старший науковий співробітник, професор кафедри іноземної філології і перекладу Київського національного торговельно-економічного університету (02156, Київ, вул. Кіото, 19); e-mail: Iryna.Zvarych7@gmail.com; orcid: https://orcid.org/0000-0002-3772-4489.

Зварич Ирина Николаевна, докт. пед. наук, старший научный сотрудник, профессор кафедры иностранной филологии и перевода Киевского национального торгово-экономического университета (02156, Киев, ул. Киото, 19); e-mail: Iryna.Zvarych7@gmail.com; orcid: https://orcid.org/0000-0002-3772-4489.

Iryna Zvarych, Doctor of Pedagogics, senior staff scientist, Full Professor, the Department of Foreign Philology and Translation, Kyiv National University of Trade and Economics (02156, Kyiv, 19 Kyoto st.); e-mail: Iryna.Zvarych7@gmail.com; orcid: https://orcid.org/0000-0002-3772-4489. 